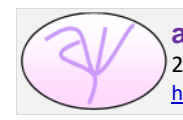

\title{
A multilevel analysis of the effects of indoor activities on psychological wellbeing during COVID-19 pandemic
}

\author{
Mehmet Çetin*, and Özgür Kökalan
}

Department of Business Administration, Faculty of Business and Management Sciences, Istanbul Sabahattin Zaim University (Turkey).

\begin{abstract}
Título: Un análisis multinivel de los efectos de las actividades en interiores sobre el bienestar psicológico durante la pandemia de COVID-19.

Resumen: El estudio tiene como objetivo analizar los efectos de las actividades en interiores tales como el ejercicio físico, la socialización digital y los juegos digitales, en los niveles de bienestar subjetivo de las personas. Dada la naturaleza dinámica de la pandemia para capturar el nivel diario dentro de la varianza individual, el estudio adapta un enfoque multinivel donde los días se anidan en personas. Se recopilan 1950 datos diarios a partir de 390 encuestados durante 5 días consecutivos durante la primera fase de la pandemia (cuando había políticas estrictas de aislamiento social) en Turquía. Los resultados de la partición de los componentes de la varianza respaldaron la necesidad de utilizar un enfoque multinivel. Los resultados del análisis realizado a través de modelos lineales jerárquicos demostraron que la actividad física a nivel diurno en el hogar y la socialización digital alivian significativamente el afecto negativo diario y se asocia positivamente con el nivel diario de afecto positivo y los niveles de felicidad de los encuestados. Estos resultados fueron controlados por variables demográficas, extraversión y resiliencia psicológica. La extraversión fue negativa y la resiliencia psicológica se relacionó positivamente con el nivel diario de afecto negativo.

Palabras clave: COVID-19. Afecto positivo y negativo. Felicidad. Activi-
\end{abstract} dad física. Socialización en línea. Juegos en línea.

\section{Introduction}

COVID-19 pandemic has severe impacts on various aspects of individuals' lives. Intertwined with economic and social effects, the psychological outcomes of the pandemic are highly critical (Qiu et al., 2020). The psychological effects of previous epidemics were much more comprehensive than the individuals exposed to the virus, and they continued to negatively affect the lives of individuals for a long time, even after the epidemic. Meta-analyzes addressing the psychological effects of epidemics such as Ebola, MERS, SARS, and COVID-19 pandemic indicate serious psychological problems such as depression, anxiety disorder, low self-esteem, loss of control, post-traumatic stress disorder, and mental disorders, which can endure even three years after the outbreak (Hossain et al., 2020; Brooks et al., 2020). In a study on 669 people who were not diagnosed with COVID 19 in India, a significant portion of the participants stated that they experienced psychological problems such as sleep disorder, paranoia, and anxiety disorder, and $80 \%$ needed professional help for their mental health (Roy et al., 2020).

\section{* Correspondence address [Dirección para correspondencia]:}

Mehmet Çetin, Ph.D, İstanbul Sabahattin Zaim University, Faculty of Business and Management Sciences, Department of Business Administration, 34303, Halkalı / Küçükçekmece- İstanbul (Turkey).

E-mail: mehmet.cetin@izu.edu.tr

(Article received: 27-9-2020, revised: 5-2-2021, accepted: 21-2-2021)
Abstract: The study aims to analyze the effects of indoor activities such as physical exercise, digital socializing, and digital gaming on the subjective wellbeing levels of individuals. Given the dynamic nature of the pandemic, to catch the day-level within individual variance (along with between individuals variance), the study adopts a multilevel approach where days are nested in people. 1950 day-level data are collected from 390 respondents for five consecutive days during the first phase of the pandemic (when there were strict social isolation policies) in Turkey. Results for partitioning variance components supported the necessity of using a multilevel approach. Findings of analysis conducted through hierarchical linear modeling demonstrated that day-level physical activity at home and digital socializing significantly alleviate daily negative affect and positively associate with day-level positive affect and happiness levels of respondents. These results were controlled for demographic variables, extraversion, and psychological resiliency. Extraversion was negatively, and psychological resiliency was positively related to day-level negative affect.

Keywords: COVID-19. Positive \& negative affect. Happiness. Physical activity. Online socializing. Online gaming.
Changes necessitating individuals to stay at home, decreased social interaction, anxiety about the health of self and relatives, economic problems, and uncertainties regarding various variables of life threaten the wellbeing of individuals during the pandemic (Dawson, \& GolijaniMoghaddam, 2020; Xiong et al., 2020). Social isolation stands as one of the most frequently applied preventative policies to reduce the spread of the virus. Despite its advantages for protecting individuals' physical health, it necessitates people to isolate themselves, stay at home and lower their physical human interaction, which may bring detrimental consequences for psychological wellbeing (Tull et al., 2020). In this process, the routines and habits of people are threatened, and they try to get used to new rules. As in the popular social campaign "life fits at home", people try to transfer or rebuild their lives, hobbies, and habits in their homes. With this given pattern of circumstances, most of the possible solutions for the problems brought by social isolation lies in indoor activities that everybody can do at their homes, such as physical exercise, digital socializing, and digital gaming.

While previous studies (e.g., Thompson et al., 2017; Diaz, \& Stewart-Ibarra; 2018) on epidemics such as H1N1 Enfluanza (2009), Ebola (2013), and Zika (2016) help us to understand the psychological effects of the COVID-19 pandemic, it is also true that this outbreak includes unique characteristics that require novel studies. Investigating the levels, antecedents, and transformation of the psychological experi- 
ences individuals experience is extremely important in terms of the information it will provide for policymakers and practitioners to manage the process effectively. Considering the dynamic nature of the process, the urgency of the studies addressing both between persons and within-person variances comes into prominence. Elements such as the spread of the virus, the total time individuals stay at home, curfews, and travel-related constraints are changing rapidly every day. Besides, the methods developed by individuals and institutions to deal with the process, their level of knowledge about the process, and their levels of getting used to new conditions also change. Each stage of the process has its own characteristics, and it is of great importance to investigate day-level within-person variance.

The main purpose of this study is to analyze the effects of indoor activities on the subjective wellbeing levels of individuals. Using a multilevel approach, the current study aims to determine the levels of happiness and positive and negative affect levels of individuals, their change over time and analyze their relationships with indoor activities (physical exercise, digital socializing, and digital gaming), personality (extraversion) and psychological resilience.

\section{Physical activity and wellbeing}

The significance of physical activity for wellbeing is wellestablished (Kim et al., 2017; Wiese, Kuykendall, \& Tay, 2018). Downward and Rasciute (2011) provided evidence for the positive link between sport (67 kinds of it) and the subjective wellbeing of individuals. Physical activity in nature demonstrates stronger connections with emotional wellbeing, where general health is connected with both indoor and outdoor physical activity (Pasanen, Tyrväinen \& Korpela, 2014). Regardless of the physical activity environment (indoor, outdoor, or combined), better scores for tension, stress, emotional outlook, and health were observed in psychically active individuals compared to inactive ones (Puett et al., 2014). The link between wellbeing and physical activity is also valid for older adults (Sasidharan et al., 2006), which were required to stay home for a long period (as it was forbidden for people older than 65 to leave home from March $21^{\text {st }}$ to June $\left.1^{\text {st }} 2020\right)$. Evidence supports the positive effects of physical activity on psychological wellbeing during the pandemic (Maugeri et al., 2020). Studies addressing indoor and outdoor exercise settings consider 'indoor' as gym centers or facilities that many people come together. Experiments (e.g., Norris, Carroll \& Cochrane, 1992) conducted for investigating the link between physical activity and wellbeing recognize the effects of social companionship provided by the exercise activity. Although with this conceptualization, indoor settings are more enabling for social interactions than outdoor settings, the latter has higher restorative quality (Hug et al., 2009). The fitness centers or any kind of public sports facilities (along with many other institutions) were closed due to the pandemic for more than two months, including the duration of the data collection process. Places like the seaside or public parks that are frequently used for jogging or walking were also closed. There were strict lockdowns requiring people to stay at their homes at weekends and holidays (with some workdays in between) during this period. Even when there was no rule-based lockdown, most people preferred to stay home due to the pandemic. All physical exercise people could do was in their houses, which changed the nature of this activity by eliminating the social side of it or reducing the machines or equipment that individuals could use. Although there is supportive evidence for the positive association between indoor exercise and wellbeing, we acknowledge that the circumstances brought by the pandemic and these forms of physical exercise are unique, and the results will be inevitably exploratory in nature.

Hypothesis 1: Daily physical activity at home will be positively related to daily positive affect and happiness and negatively related to daily negative affect.

\section{Online socializing and wellbeing}

In their comprehensive meta-analysis, Castellacci \& Tveito (2018) list some studies that are pointing the adverse effects of internet usage on wellbeing and communication (e.g., Kraut et al., 1998; Nie, 2001) and some others that are providing positive associations between the variables (e.g., Valkenburg \& Peter, 2009; Kraut et al., 2002). They argue that the link between those is complex and personal characteristics and the life domain in which the Internet is used affect the association. If it is used for saving time for enhancing social interactions, it can create a positive impact on wellbeing.

Accordingly, recent studies indicate different natures of associations between variables. Kim (2017) provides evidence for the negative link between online social networking and psychological state. Dhir et al. (2018) showed that compulsive usage of social media induces fatigue, and social media fatigue boosts anxiety and depression.

On the other hand, Coyne et al. (2020), via an eight-years longitudinal study, demonstrated no significant relationship between the time spent using social media and personal changes in depression and anxiety. Law, Shapka, \& Collie (2020) showed that online experiences may affect individuals in different ways. Their findings classified respondents into three profiles in accordance with their social acceptance, depression, and anxiety levels. $61 \%$ of the participants were in the moderate cluster, and $31 \%$ were in the flourishing profile, while only $8 \%$ were in the languishing group.

Studies base the adverse effects of using the Internet for social interaction on substituting face-to-face communication and decreasing the physical (actual) human contact, but no studies have ever addressed these associations when using the Internet or digital channels become the only way to interact with others that are not living in the same house.

Coget, Yamauchi \& Suman (2002)'s findings revealed that online socializing decreased the levels of loneliness, and 
this decrease was not statistically different from the impact of face-to-face socializing on loneliness. Kim \& Lee (2011) provide evidence for the positive relationship between the number of Facebook friends and subjective wellbeing. Valenzuela, Park \& Kee (2009) indicate a positive link between Facebook usage and life satisfaction. Przybylski \& Weinstein (2017) indicate a quadratic relationship between digital screen use and mental wellbeing. It is important to note that these findings were mainly developed with adolescent samples and, more importantly, under normal circumstances. Social distancing and lockdowns can change the function, and meaning individuals attribute to digital channels of communication.

Selfhout et al. (2009) indicated that the relationship between depressive symptoms and online socializing is negative for children who have low-quality friendships, as they can have social support from online channels, which they cannot normally have from traditional channels. Although it is not the same situation, there is a resemblance given the circumstances of social distancing and lockdowns, as individuals cannot socialize in the traditional ways, and online channels are providing a solid substitute.

Hypothesis 2: Daily online socializing will be positively related to daily positive affect and happiness and negatively related to daily negative affect.

\section{Online gaming and wellbeing}

Findings for the links between gaming and wellbeing in the literature depict a complex picture rather than an agreedupon nature of the association. The way individuals engage in gaming (obsessive or harmonious) and the time they spent on it (excessive or moderate) is significantly determinative for whether gaming results in positive or negative outcomes (Lafreniere et al., 2009). Also, these associations may be contingent across cultures and countries (Cheng, Cheung, \& Wang, 2018).

Some studies suggest a negative link between gaming and wellbeing, especially when it is in an extreme form. Excessive levels of gaming or game addiction are positively related to depression, anxiety, and loneliness (Wang, Sheng, \& Wang, 2019). Video game use can have detrimental effects such as suicidal tendencies and interpersonal violence (Ivory, Ivory, \& Lanier, 2017).

On the other hand, Halbrook, O'Donnell, \& Msetfi (2019) suggested that video games are good for psychological health when used in healthy ways that induce social activity. King et al. (2020) emphasize the role of more balanced styles of gaming for supporting the wellbeing of individuals during the pandemic. Video gaming can reduce stress levels and enhance happiness and mental health through positive emotions, engagement, meaning, and accomplishment (Jones et al., 2014). Even violent games can enhance creativity and emotional wellbeing (Kutner \& Olson 2009). Gamers are likely to be generally observed as more antisocial individuals.
However, digital gaming can serve as a socializing tool. Online social interaction is an essential moderator in the relationship between video gaming and depressive symptoms (Carras et al., 2017). Individuals with higher online social interaction can relate to a virtual social community, build friendships and show fewer depressive symptoms.

Hypothesis 3: Daily online gaming will be positively related to daily positive affect and happiness and negatively related to daily negative affect.

\section{Extraversion and wellbeing}

Extraversion has been generally accepted as a positive predictor for wellbeing as it is assumed that extraverts experience more positive affect and happiness and less negative affect given the same circumstances (McCrae Costa, 1991; Zelenski \& Larsen, 1999; Olesen, Thomsen, \& O’Toole, 2015: Hervas, \& López-Gómez, 2016). "The bulk of the literature on the personality correlates of happiness can be summarized by saying that more extraverted and more adjusted people are happier" (Costa \& McCrae, 1980, p.674). Lee, Dean \& Jung (2008) report positive relationships between extraversion positive affect and life satisfaction and negative association with negative affect. Harris \& Lightsey (2005)'s findings indicate the same relationship pattern and add a positive link between extraversion and happiness. Despite this general view regarding extraversion and wellbeing, we believe the circumstances entailed by the pandemic can reverse this relationship. Compulsory lockdowns, social distancing, and staying at home would be less tolerated by extroverts compared to introverts who are more used to and indifferent to such situations in their normal lives. We propose a negative relationship between extraversion and wellbeing.

Hypothesis 4: Extraversion will be negatively related to daily positive affect and happiness and positively related to daily negative affect.

\section{Psychological resiliency and wellbeing}

Psychological resilience can be defined as the ability and power of individuals to recover rapidly from severe psychological adversities and strains without serious and longlasting harms to wellbeing (Fletcher \& Sarkar, 2013; Wagnild and Young, 1993). By definition, psychological resiliency is positively linked with wellbeing. Numerous studies support this link with evidence (e.g., Mayordomo et al., 2016). Psychological resilience is positively linked with life satisfaction and negatively related to depression ( $\mathrm{Mak}, \mathrm{Ng} \&$ Wong, 2011); higher general health perception, job satisfaction, and lower levels of exhaustion and physical illness (Pretsch, Flunger \& Schmitt 2012). Individuals experience life events that can be highly stressful and traumatic during the pandemic. People experience or witness others losing their jobs, 
lives, and loved ones all around the world. Just hearing thousands of people dying in a day due to COVID-19 is traumatic itself. We propose that resiliency will be a strong determinant of how such life events affect individuals and we take psychological resiliency as a control variable into our analysis with general levels of physical activity, socializing, online gaming, and happiness.

\section{Method}

\section{Sample Procedure and Measure}

Respondents were selected via a convenience sampling approach and connected through digital channels given the circumstances of the pandemic. All data were collected through online forms. Respondents who were under high school age (14), who did not provide one complete person level or five complete day level (consecutive) data, who were diagnosed with Covid -19 during the data collection process were excluded. Only respondents with consent and willingness to participate and living in Turkey were included. Convenience sampling was used in this process. Participants were informed about the procedure, and the nature of the study, and they filled daily forms for five consecutive days and the longer person-level questionnaire one week after they finished the daily phase. 390 participants provided one person-level and five day-level responses each. Analyses were conducted with 1950 day-level and 390 person-level data. Responses were matched via a code provided by the participants in each form. No personal information was asked, and all participants were volunteers.

We measured daily positive and negative affect, daily happiness, daily time spent for exercise, daily time spent on digital games, and daily time spent for socializing for five consecutive days with a short form. Data regarding general happiness, extraversion, psychological resiliency, time spent on digital socializing, gaming, and exercising in general, total time spent at home from the beginning of the pandemic, number of people living at home, the nature of change in the household income and demographics were measured with a lengthier survey delivered one time one week after the daily surveys.

We used The Positive and Negative Affect Scale (PANAS) developed by Watson, Clark, and Tellegen (1988) and adapted to Turkish by Gençöz (2000). To assess daily negative and positive affect levels of participants, the wording in the instructions of the scale was modified slightly for asking the frequency of the relevant emotions experienced on that day. We used three items for positive affect 'enthusiastic', 'strong', 'active'; and four items for negative affect 'nervous', 'upset', 'distressed', and 'irritable'. We selected these items for three reasons; first, we wanted to keep the daily questionnaire (one delivered five days) short and less demanding for participants to increase the response rate and usable data. Second, these items were more suitable for asking day-level experiences. Last, they were the most relevant ones for the aim of the study and the conditions entailed by the pandemic.

The Happiness Scale developed by Demirci \& Ekşi (2018) was used for assessing the daily happiness levels of participants. The authors provided high validity and reliability for the scale, which has a one-factor structure and consists of 6 items. We used all six items in both forms (daily and person-level), and small modifications were made on the wording of the items and instructions for converting it to a daily measure.

Items of the 5-factor Personality Inventory developed by John, Donahue \& Kentle (1991) and adapted to Turkish by Sümer, Lajunen, \& Özkan (2005) are used for assessing extraversion levels of respondents. All items of the scale assessing extraversion were utilized in the person-level form.

To determine the psychological resilience levels of respondents, the measure developed by Friborg et al. (2003) was used. The scale was validated for Turkish by Basim \& Çetin (2011).

Asking the frequency of the behavior or the time spent for such activity is frequently used in several studies that are addressing socialization, gaming, and physical activity (e.g., Fuligni, \& Hardway, 2006; Hellström et al., 2012; Przybylski, 2014; Männikkö, Billieux, \& Kääriäinen; 2015; Mills et al., 2018). Daily time spent for exercise, digital gaming, and digital socializing were assessed via asking single item openended questions asking the time respondents spent for such activities. Likely, we asked how much time respondents spent at home in total because of the pandemic, and the number of people living at home was asked with single questions. The nature of change in the household income due to pandemic was asked by simply asking a categorical question with options ranging from 'it decreased a lot' to 'it increased a lot'. Gender, level of education, and marital status were asked with categorical questions. Age was asked as an openended question.

$60 \%$ of the respondents were female, $69 \%$ were single, and $61 \%$ of the respondents were university graduates, $27 \%$ of them were high school graduates. The average age was 29 ranging from 14 to 85 . Participants were under lockdown at home for an average of 25 days. 4,5 people were on average were living in the houses of the respondents. $47 \%$ indicated that their household income was decreased due to the pandemic. $10 \%$ answered as their income decreased drastically and $39 \%$ responded no change, and 3\% indicated an increase in their household income.

\section{Analysis}

We adopted a multilevel analysis approach where days were nested in individuals. Hypotheses were tested using hierarchical Multiple Linear Modeling via HLM statistical program (Raudenbush, Bryk \& Congdon, 2011) HLM 7.00 for Windows. Prior to the tests for our hypotheses, we partitioned the within-person variance with total variance (between-person variance plus within-person variance) for test- 
ing the properness of using a multilevel approach. Results showed that significant amounts $(57 \%$ to $65 \%$ see table 1$)$ of the total variance for daily measured variables were level 1 (within-person) variance, and this is an indicator of the necessity for using multilevel approaches.

Table 1.

Variance distribution of day-level variables.

\begin{tabular}{|c|c|c|c|c|c|c|c|}
\hline Variable & Intercept & Within-person variance & Between-person variance & Percent of Within-person variance & Reliability & Means & tan. Dev. \\
\hline NA & $2.50 * *$ & 0.66 & 0.49 & 57 & 0.79 & 2.5000 & .02426 \\
\hline PA & $3.08^{* *}$ & 0.62 & 0.42 & 60 & 0.77 & 3.0809 & .02303 \\
\hline Happiness & $3.27 * *$ & 0.66 & 0.35 & 65 & 0.79 & 3.2780 & .02278 \\
\hline Exercise & $31.51 * *$ & 1886.32 & 1238.25 & 60 & 0.77 & 31.520 & 1.2650 \\
\hline Dig. Gaming & $42.78^{* *}$ & 3356.63 & 2745.44 & 55 & 0.80 & 42.780 & 1.7680 \\
\hline Dig. Social. & $124.73^{* *}$ & 12529.23 & 8210.50 & 60 & 0.77 & 124.73 & 3.2600 \\
\hline
\end{tabular}

Note: $\mathrm{PA}=$ positive affect, NA = negative affect, Dig. Gaming = daily time spent on digital gaming, Dig. Social.= daily time spent on digital socializing, Exercise $=$ daily time spent on exercising

$00=$ average intercept across participants. The percent of day level variance was as calculated as $\sigma 2 /(\sigma 2+\tau 00)$

$* * p<.01$.

Prior to hypothesis testing, we calculated the zero-order relationships between variables. Correlations were computed at different levels and across different levels via two methods. All daily variables were aggregated to their means across days for each person, and these scores were used for calculating the correlations among day-level and person-level variables. This is like the conventional method, but just asking some variables for five days (and taking their means) instead of asking them once. The other method was designed for taking both variance levels into account and calculating the associations with a multilevel approach via using variance difference scores produced in HLM.

Scores provide preliminary support for the propositions of the study. Daily exercise, digital gaming, and digital socializing demonstrate significant associations with the dependent variables of the study. Aggregated scores and multilevel scores for NA, PA, and Happiness together provide significant links with exercise, digital gaming, and digital socializing. Extraversion, general happiness, and psychological resiliency demonstrated significant associations with the study variables. Associations will be tested further through multilevel analysis.

We created multilevel random coefficient models for testing the study hypothesis with day-level and person-level variables. Control variables, age, gender, education, total time spent home under lockdown, change in household income, number of people living at home demonstrated no significant relationship with any of the dependent variables; thus, they were excluded from the table for simplicity. Marital status showed significant relations with dependent variables. Being married was linked with higher levels of happiness, positive affect, and lower levels of negative affect.

Results indicate significant relations between daily exercise and daily digital socializing with all three of the dependent variables in the way that was proposed by the study. Thus, hypotheses 1 and 2 are fully supported. On the days respondents spend more time exercising and digital socializing, they experienced higher levels of happiness and positive affect and lower levels of negative affect. Day-level digital gaming showed no significant association with any of the dependent variables. Hypothesis 3 is not supported. The general level of digital gaming showed a positive relationship with NA.

Table 2.

Zero-order associations between study variables.

\begin{tabular}{|c|c|c|c|c|c|c|}
\hline & 1 & 2 & 3 & 4 & 5 & 6 \\
\hline 1. NA & 1 & $-.247 * *$ & $-.442^{* *}$ & $.119 *$ & $.152 * *$ & -.044 \\
\hline 2. PA & $-.527 * *$ & 1 & $.754 * *$ & $.211 * *$ & .082 & $.119 *$ \\
\hline 3. Happiness & $-.598 * *$ & $.676^{* *}$ & 1 & $.177 * *$ & .007 & .087 \\
\hline 4. Exerci & $-.050^{\mathrm{a}}$ & $.126 * *$ & $.065^{*}$ & 1 & $.430 * *$ & $.135^{* *}$ \\
\hline 5. Dig. C & -.04 & -.024 & $.042^{\mathrm{a}}$ & $.118^{*}$ & 1 & $.199 * *$ \\
\hline 6. Dig. Social. & $-.073^{*}$ & $.154^{* *}$ & $.140^{*}$ & .003 & $.191 *$ & 1 \\
\hline 7. Days & -.024 & $-.062 *$ & .000 & .007 & .000 & .003 \\
\hline 8. Gender & -.04 & .046 & -.012 & .096 & $.177^{* *}$ & .015 \\
\hline 9. Marital S. & $-.105^{*}$ & $.123 *$ & $.145^{* *}$ & -.028 & -.093 & $-.181 * *$ \\
\hline 10. Education & .025 & -.092 & -.073 & .034 & -.021 & .021 \\
\hline 11. Age & $-.113^{*}$ & .070 & .098 & -.056 & -.096 & $-.122^{*}$ \\
\hline 12. Extra & -.010 & $.133^{* *}$ & $.108^{*}$ & .074 & .021 & .034 \\
\hline 13. Happin & $-.142 * *$ & $.139 * *$ & $.227 * *$ & .054 & -.059 & .012 \\
\hline 14. Psy. Resiliency. & $-.209 * *$ & $.103^{*}$ & .069 & $-.151 * *$ & $-.120^{*}$ & .001 \\
\hline
\end{tabular}

Note: $\mathrm{PA}=$ positive affect, $\mathrm{NA}=$ negative affect, Dig. Gaming $=$ daily time spent on digital gaming, Dig. Social.= daily time spent on digital socializing, Exercise $=$ daily time spent on exercising. Correlations over the diagonal are computed with aggregated scores across five days $(\mathrm{N}=390)$. Correlations under the diagonal are day-level (within-person) correlations and were computed through group-centered one-predictor equations $(\mathrm{N}=1950)$. Correlations with the person-level variables are Pearson's coefficients and were calculated with participants' aggregated daily scores.

** Correlation is significant at the .01 level (2-tailed).

* Correlation is significant at the .05 level (2-tailed).

The level of extraversion was positively associated with NA as proposed by the hypothesis 4 . Extravert participants were more negatively affected by the circumstances brought by the pandemic. Extraversion level was significantly and positively related to NA (est $=0.20$ and $t=3.20$ ). Psychological resiliency was negatively associated with NA. Results provided no evidence for significant relationships between Extraversion and Psychological resiliency with PA and Happiness. In conclusion, hypotheses 1 and 2 are fully supported, hypothesis 4 is partly supported, and hypothesis 3 is not supported. 
Table 3.

Multilevel estimates for models predicting dependent variables of the study.

\begin{tabular}{|c|c|c|c|c|c|c|c|c|c|}
\hline \multirow[b]{2}{*}{ Variable } & \multicolumn{3}{|c|}{ NA } & \multicolumn{3}{|c|}{ PA } & \multicolumn{3}{|c|}{ Happiness } \\
\hline & Est & $\mathrm{SE}$ & $t$ & Est & SE & $t$ & Est & SE & $t$ \\
\hline Intercept & 2.76 & 0.21 & $12.62 * * *$ & 2.95 & 0.19 & $14.79 * *$ & 3.02 & 0.20 & $14.87 * *$ \\
\hline Marital St. & -0.00 & 0.13 & $-0.05^{*}$ & 0.21 & 0.10 & $1.92 *$ & 0.19 & 0.10 & 1.83* \\
\hline Exercise (L2) & -0.03 & 0.03 & -0.94 & 0.05 & 0.04 & 1.25 & 0.04 & 0.03 & 1.34 \\
\hline D. Gam. (L2) & 0.08 & 0.02 & $2.92^{* *}$ & 0.00 & 0.02 & 0.05 & -0.03 & 0.02 & -1.13 \\
\hline D. Socia. (L2) & -0.10 & 0.03 & $-2.98 * *$ & -0.04 & 0.03 & -1.43 & -0.01 & 0.03 & -0.31 \\
\hline Happiness & -0.15 & 0.06 & $-2.41 * *$ & 0.10 & 0.06 & 1.62 & 0.21 & 0.06 & 3.56 *** \\
\hline Extraversion & 0.20 & 0.06 & $3.20 * *$ & 0.04 & 0.05 & 0.79 & -0.02 & 0.05 & -0.36 \\
\hline Psych. Res. & -0.14 & 0.04 & $-3.30 * *$ & 0.03 & 0.04 & 0.85 & -0.01 & 0.03 & -0.33 \\
\hline Days & -0.02 & 0.01 & -1.60 & 2.95 & 0.19 & $-1.79 *$ & -0.00 & 0.00 & 0.51 \\
\hline Exercise & -0.00 & 0.00 & $-3.30 * *$ & 0.05 & 0.07 & $6.48^{* * *}$ & 0,00 & 0,01 & $4.22 * * *$ \\
\hline D. Gaming & 0.00 & 0.00 & 0.06 & 0.21 & 0.10 & -1.63 & 0,00 & 0,00 & 0.32 \\
\hline Socializing & -0.00 & 0.00 & $-2.10 * *$ & -0.03 & 0.04 & $5.99 * * *$ & 0,00 & 0,00 & $5.65^{* * *}$ \\
\hline
\end{tabular}

\section{Discussion and Conclusion}

The study aimed to investigate the effects of physical exercise, digital socializing, and digital gaming on happiness and positive and negative affect levels of individuals. The data collection period was the first week of May 2020, where there were strict rules for staying at home for age groups 20 and younger and 65 and older. There were lockdowns on weekends and holidays for everyone except some working groups (e.g., health care professionals). Besides, all places for any kind of group meetings (seaside, shopping malls, diners, restaurants, cafes, gyms, etc.) were closed. Travel restrictions forbade intercity travels. There were strong campaigns such as "stay home" or "life fits at home" advising people to stay home. Education was transferred online. Most organizations supported online and distance working.

Considering the dynamic nature of the pandemic and people's reactions to it, we assumed a significant withinindividual variance in the variables and designed a multilevel research model. Results of the preliminary analysis supported our assumption and the significance of using multilevel analysis. Findings supported the proposed relationships regarding day-level physical activity at home and digital socializing. They both increased the levels of day-level positive affect and happiness and decreased negative affect. On the other hand, daily online gaming did not relate significantly to any of the dependent variables. Studies that addressed the link between physical activity and psychological wellbeing during the pandemic support our findings (Maugeri et al., 2020).

Some findings in the literature regarding the outcomes of gaming demonstrate a positive nature (e.g., Jones et al., 2014; Kutner \& Olson 2009), while some describe a negative one (e.g., Wang, Sheng, \& Wang, 2019; Ivory, Ivory, \& Lanier, 2017). The balance and excessiveness in the amount of time spent on gaming can be determinative on these conflicting findings. Several studies investigating gaming and wellbeing association indicate a curvilinear (U-shaped) relationship (e.g., Allahverdipour et al., 2010; Yamaguchi, 2020). We tested if there is a bending point for this link through a series of regression analyses. Results demonstrated no significant quadratic relationship. As mentioned earlier in the paper, the factors brought by the pandemic are unique, and even highly established associations are re-explored under these circumstances. One example from the current study is the positive link between extraversion and negative affect, which is contrary to the general stream of findings on this matter (e.g., Gale et al., 2013; Vittersø \& Nilsen, 2002). Introverts are less affected by the lockdown and social distancing as they are more likely to consider these conditions as their normal. Socializing and companionship of others are more indispensable and habitual for extroverts.

In conclusion, daily physical exercise and digital socializing can help to mitigate the adverse psychological effects of the pandemic by increasing PA and happiness levels and decreasing NA levels. Social distancing constitutes an effective measure in the pandemic process, and it reduces social interaction, which plays an important role in dealing with the negative psychological outcomes of the pandemic, boosting the loneliness levels that will increase these negative outcomes (Van Bavel et al., 2020). During this unique and challenging time, socializing through online channels and physical activity at home stands as simple and effective ways to cope with the negative psychological outcomes of the pandemic. Excuses for inactivity are mostly intrinsic (Nahas, Goldfine, \& Collins, 2003), and people can exercise everywhere, even by using their own body weight when there is no equipment. It is never the same with face-to-face communication but still, findings indicate that digital socializing can demonstrate the same nature and pattern of relationship (Coget, Yamauchi \& Suman 2002). Policymakers can alter the wellbeing levels of individuals by advising physical activity and online socializing through public broadcasts, social campaigns, and awareness-building programs that are informing individuals on how to deal with the pandemic.

Although daily multilevel research design enabled us to explain the intra-individual and inter-individual variance, due to the difficulties in collecting daily data, we preferred to use shorter forms to make it easier for respondents to follow up for five consecutive days. More comprehensive analysis (that requires longer forms) on the type and content of gaming can enhance our understanding of the daily consequences of 
online gaming. Motivation to play can affect the outcomes of gaming more than the time spent on the activity (Hellström et al., 2012). Cultural characteristics can also affect the links between gaming and its possible consequences (Cheng, Cheung, \& Wang, 2018). Comparative studies addressing the pandemic period can expand the knowledge on the matter. Readers should keep in mind that the data collection period

\section{References}

Allahverdipour, H., Bazargan, M., Farhadinasab, A., \& Moeini, B. (2010). Correlates of video games playing among adolescents in an Islamic country. BMC Public Health, 10(1), 286. https://doi.org/10.1186/14712458-10-286

Basim, H. N., \& Çetin, F. (2011). Yetișkinler için psikolojik davanıklılık ölçeği'nin güvenilirlik ve geçerlilik çalışması [Reliability and validity study of the resilience scale for adults]. Türk Psikiyatri Dergisi, 22(2), 104-114.

Brooks, S. K., Webster, R. K., Smith, L. E., Woodland, L., Wessely, S., Greenberg, N., \& Rubin, G. J. (2020). The psychological impact of quarantine and how to reduce it: rapid review of the evidence. The Lancet.

Carras, M. C., Van Rooij, A. J., Van de Mheen, D., Musci, R., Xue, Q. L., \& Mendelson, T. (2017). Video gaming in a hyperconnected world: A cross-sectional study of heavy gaming, problematic gaming symptoms, and online socializing in adolescents. Computers in Human Behavior, 68 , 472-479. https://doi.org/10.1016/j.chb.2016.11.060

Castellacci, F., \& Tveito, V. (2018). Internet use and well-being: A survey and a theoretical framework. Research policy, 47(1), 308-325.

Cheng, C., Cheung, M. W. L., \& Wang, H. Y. (2018). Multinational comparison of internet gaming disorder and psychosocial problems versus well-being: Meta-analysis of 20 countries. Computers in Human Behavior, 88, 153-167.

Coget, J. F., Yamauchi, Y., \& Suman, M. (2002). The Internet, social networks and loneliness. It \& Society, 1(1), 180-201.

Costa, P. T., \& McCrae, R. R. (1980). Influence of extraversion and neuroticism on subjective well-being: happy and unhappy people. Journal of Personality and Social Psychology, 38(4), 668. https://doi.org/10.1037/00223514.38.4.668

Coyne, S. M., Rogers, A. A., Zurcher, J. D., Stockdale, L., \& Booth, M. (2020). Does time spent using social media impact mental health?: An eight year longitudinal study. Computers in Human Behavior, 104, 106160.

Dawson, D. L., \& Golijani-Moghaddam, N. (2020). COVID-19: Psychological flexibility, coping, mental health, and wellbeing in the UK during the pandemic. Journal of contextual behavioral science, 17, 126-134.

Demirci, İ. \& Ekşi. H. (2018). Keep calm and be happy: A mixed method study from character strengths to well-being. Educational Sciences: Theor o Practice 18(29) 303-354. http://dx.doi.org/10.12738/estp.2018.2.0799

Dhir, A., Yossatorn, Y., Kaur, P., \& Chen, S. (2018). Online social media fatigue and psychological wellbeing-A study of compulsive use, fear of missing out, fatigue, anxiety and depression. International Journal of Information Management, 40, 141-152.

Diaz, A., \& Stewart-Ibarra, A. M. (2018). Zika virus infections and psychological distress following natural disasters. Future Virology, 13(6), 379.

Downward, P., \& Rasciute, S. (2011). Does sport make you happy? An analysis of the well-being derived from sports participation. International Review of Applied Economics, 25(3), 331-348. https://doi.org/10.1080/02692171.2010.511168

Fletcher, D., \& Sarkar, M. (2013). Psychological resilience: A review and critique of definitions, concepts, and theory. European Psychologist, 18(1), 12. https://doi.org/10.1027/1016-9040/a000124

Friborg, O., Hjemdal , O., Rosenvinge, JH ., \& Martinusseni M. (2003). A New Rating Scale for Adult Resilience: What are the Central Protective Resources behind Healthy Adjustment?. International Journal of Methods Psychiatric Research, 12(2), 65-76. https://doi.org/10.1002/mpr.143. entailed unique circumstances due to the pandemic. Considering the dynamic nature of the conditions brought by the pandemic, studies targeting longer periods and different phases of the pandemic can further explain the relationships among study variables and provide more generalizable outcomes.

Fuligni, A. J., \& Hardway, C. (2006). Daily variation in adolescents' sleep, activities, and psychological well-being. Journal of Research on Adolescence, 16(3), 353-378.

Gale, C. R., Booth, T., Mõttus, R., Kuh, D., \& Deary, I. J. (2013). Neuroticism and Extraversion in youth predict mental wellbeing and life satisfaction 40 years later. Journal of Research in Personality, 47(6), 687-697. https://doi.org/10.1016/j.jrp.2013.06.005

Gençöz, T. (2000). Pozitif ve negatif duygu ölçeği: Geçerlik ve güvenirlik çalışması [Positive and negative affect scale: Validity and reliability study]. Türk Psikoloji Dergisi, 15(46), 19-26.

Halbrook, Y. J., O'Donnell, A. T., \& Msetfi, R. M. (2019). When and how video games can be good: A review of the positive effects of video games on well-being. Perspectives on Psychological Science, 14(6), 1096-1104.

Harris, P. R., \& Lightsey Jr, O. R. (2005). Constructive thinking as a mediator of the relationship between extraversion, neuroticism, and subjective well-being. European Journal of Personality: Published for the European Association of Personality Psychology, 19(5), 409-426. https://doi.org/10.1002/per.544

Hellström, C., Nilsson, K. W., Leppert, J., \& Åslund, C. (2012). Influences of motives to play and time spent gaming on the negative consequences of adolescent online computer gaming. Computers in buman behavior, 28(4), 1379-1387.

Hervas, G., \& López-Gómez, I. (2016). The power of extraverts: Testing positive and negative mood regulation. Anales de psicologia, 32(3), 710716.

Hossain, M. M., Sultana, A., \& Purohit, N. (2020). Mental health outcomes of quarantine and isolation for infection prevention: A systematic umbrella review of the global evidence. Available at SSRN 3561265.

Hug, S. M., Hartig, T., Hansmann, R., Seeland, K., \& Hornung, R. (2009) Restorative qualities of indoor and outdoor exercise settings as predictors of exercise frequency. Health \& Place, 15(4), 971-980. https://doi.org/10.5167/uzh-26960

Ivory, A. H., Ivory, J. D., \& Lanier, M. (2017). Video game use as risk exposure, protective incapacitation, or inconsequential activity among university students. Journal of Media Psychology.

John, O. P., Donahue, E. M., \& Kentle, R. L. (1991). The big five inventory- versions $4 \mathrm{a}$ and 54 .

Jones, C., Scholes, L., Johnson, D., Katsikitis, M., \& Carras, M. C. (2014) Gaming well: links between videogames and flourishing mental health. Frontiers in Psychology, 5, 260 https://doi.org/10.3389/ fpsyg.2014.00260

Kim, E. S., Kubzansky, L. D., Soo, J., \& Boehm, J. K. (2017). Maintaining healthy behavior: a prospective study of psychological well-being and physical activity. Annals of Behavioral Medicine, 51(3), 337-347.

Kim, H. H. S. (2017). The impact of online social networking on adolescent psychological well-being (WB): a population-level analysis of Korean school-aged children. International Journal of Adolescence and Youth, 22(3), 364-376.

Kim, J., \& Lee, J. E. R. (2011). The Facebook paths to happiness: Effects of the number of Facebook friends and self-presentation on subjective well-being. CyberPsychology, Behavior, and Social Networking, 14(6), 359-364. https://doi.org/10.1089/cyber.2010.0374

King, D. L., Delfabbro, P. H., Billieux, J., \& Potenza, M. N. (2020). Problematic online gaming and the COVID-19 pandemic. Journal of Behavior al Addictions. 
Kraut, R., Kiesler, S., Boneva, B., Cummings, J., Helgeson, V., \& Crawford, A. (2002). Internet paradox revisited. Journal of Social Issues, 58(1), 49-74. https://doi.org/10.1111/1540-4560.00248

Kraut, R., Patterson, M., Lundmark, V., Kiesler, S., Mukophadhyay, T., \& Scherlis, W. (1998). Internet paradox: A social technology that reduces social involvement and psychological well-being?. American Psychologist, 53(9), 1017. https://doi.org/10.1037//0003-066x.53.9.1017.

Kutner, L., \& Olson, C. (2009). Grand Theft Childhood: The Surprising Truth About Violent Video Games and What Parents Can Do. New York: Simon \& Schuster

Lafreniere, M. A. K., Vallerand, R. J., Donahue, E. G., \& Lavigne, G. L. (2009). On the costs and benefits of gaming: The role of passion. CyberPsychology \& Behavior, 12(3), 285-290. https://doi.org/10.1089/cpb.2008.0234

Law, D. M., Shapka, J. D., \& Collie, R. J. (2020). Who might flourish and who might languish? Adolescent social and mental health profiles and their online experiences and behaviors. Human Behavior and Emerging Technologies, 2(1), 82-92.

Lee, R. M., Dean, B. L., \& Jung, K. R. (2008). Social connectedness, extraversion, and subjective well-being: Testing a mediation model. Personality and Individual Differences, 45(5), 414-419. https://doi.org/10.1016/j.paid.2008.05.017

Mak, W. W., Ng, I. S., \& Wong, C. C. (2011). Resilience: enhancing well-being through the positive cognitive triad. Journal of Counseling Psychology, 58(4), 610. https://doi.org/10.1037/a0025195.

Männikkö, N., Billieux, J., \& Kärriäinen, M. (2015). Problematic digital gaming behavior and its relation to the psychological, social and physical health of Finnish adolescents and young adults. Journal of behavioral addictions, 4(4), 281288.

Maugeri, G., Castrogiovanni, P., Battaglia, G., Pippi, R., D'Agata, V., Palma, A., ... \& Musumeci, G. (2020). The impact of physical activity on psychological health during Covid-19 pandemic in Italy. Heliyon, 6(6), e04315.

Mayordomo, T., Viguer, P., Sales, A., Satorres, E., \& Meléndez, J. C. (2016). Resilience and coping as predictors of well-being in adults. The Journal of Psychology, 150(7), 809-821. https://doi.org/10.1080/00223980.2016.1203276

McCrae, R. R., \& Costa Jr, P. T. (1991). Adding Liebe und Arbeit: The full fivefactor model and well-being. Personality and Social Psychology Bulletin, 17(2), 227-232. https://doi.org/10.1177/014616729101700217

Mills, D. J., Milyavskaya, M., Mettler, J., Heath, N. L., \& Derevensky, J. L. (2018). How do passion for video games and needs frustration explain time spent gaming?. British Journal of Social Psychology, 57(2), 461-481.

Nahas, M. V., Goldfine, B., \& Collins, M. A. (2003). Determinants of physical activity in adolescents and young adults: The basis for high school and college physical education to promote active lifestyles. Physical Educator, 60(1), 42.

Nie, N. H. (2001). Sociability, interpersonal relations, and the Internet: Reconciling conflicting findings. American Behavioral Scientist, 45(3), 420-435. https://doi.org/10.1177/00027640121957277

Norris, R., Carroll, D., \& Cochrane, R. (1992). The effects of physical activity and exercise training on psychological stress and well-being in an adolescent population. Journal of Psychosomatic Research, 36(1), 55-65. https://doi.org/10.1016/0022-3999(92)90114-h

Olesen, M. H., Thomsen, D. K., \& O'Toole, M. S. (2015). Subjective well-being: Above neuroticism and extraversion, autonomy motivation matters. Personality and Individual Differences, 77, 45-49.

Pasanen, T. P., Tyrväinen, L., \& Korpela, K. M. (2014). The relationship between perceived health and physical activity indoors, outdoors in built environments, and outdoors in nature. Applied Psychology: Health and Well-Being, 6(3), 324-346. https://doi.org/10.1111/aphw.12031

Pretsch, J., Flunger, B., \& Schmitt, M. (2012). Resilience predicts well-being in teachers, but not in non-teaching employees. Social Psychology of Education, 15(3), 321-336. https://doi.org/10.1007/s11218-012-9180-8

Przybylski, A. K. (2014). Electronic gaming and psychosocial adjustment. Pediatrics, 134(3), e716-e 722.

Przybylski, A. K., \& Weinstein, N. (2017). A large-scale test of the goldilocks hypothesis: quantifying the relations between digital-screen use and the mental well-being of adolescents. Psychological Science, 28(2), 204-215. https://doi.org/10.1177/0956797616678438

Puett, R., Teas, J., España-Romero, V., Artero, E. G., Lee, D. C., Baruth, M., ... \& Blair, S. N. (2014). Physical activity: does environment make a difference for tension, stress, emotional outlook, and perceptions of health status?. Journal of Physical Activity and Health, 11(8), 1503-1511. https://doi.org/10.1123/ipah.2012-0375

Qiu, J., Shen, B., Zhao, M., Wang, Z., Xie, B., \& Xu, Y. (2020). A nationwide survey of psychological distress among Chinese people in the COVID-19 epidemic: implications and policy recommendations. General Psychiatry, 33(2). https://doi.org/10.1136/gpsych-2020-100213.

Raudenbush, S. W., Bryk, A. S., \& Congdon, R. (2011). HLM 7.00 for Windows. Skokie (Illinois): Scientific Software International.

Roy, D., Tripathy, S., Kar, S. K., Sharma, N., Verma, S. K., \& Kaushal, V. (2020). Study of knowledge, attitude, anxiety \& perceived mental healthcare need in Indian population during COVID-19 pandemic. Asian Journal of Psycbiatry, 102083. https://doi.org/10.1016/j.ajp.2020.102083

Sasidharan, V., Payne, L., Orsega-Smith, E., \& Godbey, G. (2006). Older adults' physical activity participation and perceptions of wellbeing: Examining the role of social support for leisure. Managing Leisure, 11(3), 164-185. https://doi.org/10.1080/13606710600715242

Selfhout M. H. W., Branje S. J. T., Delsing M. et al., (2009). Different types of Internet use, depression, and social anxiety: The role of perceived friendship quality. Journal of Adolescence, 32, 819-833. https//doi.org/10.1016/j.adolescence.2008.10.011

Sümer, N., Lajunen, T., \& Özkan, T. (2005). Big five personality traits as the distal predictors of road accident. Traffic and Transport Psychology: Theory and Application, 215, 215-227.https://doi.org/10.1016/B978-008044379-9/50173-4

Thompson, R. R., Garfin, D. R., Holman, E. A., \& Silver, R. C. (2017). Distress, worry, and functioning following a global health crisis: A national study of Americans' responses to Ebola. Clinical psychological science, 5(3), 513-521.

Tull, M. T., Edmonds, K. A., Scamaldo, K., Richmond, J. R., Rose, J. P., \& Gratz, K. L. (2020). Psychological Outcomes Associated with Stay-at-Home Orders and the Perceived Impact of COVID-19 on Daily Life. Psychiatry research, 113098.

Valenzuela, S., Park, N., \& Kee, K. F. (2009). Is there social capital in a social network site?: Facebook use and college students' life satisfaction, trust, and participation. Journal of Computer-Mediated Communication, 14(4), 875-901. https://doi.org/10.1111/j.1083-6101.2009.01474.x

Valkenburg, P. M., \& Peter, J. (2009). Social consequences of the Internet for adolescents: A decade of research. Current Directions in Psychological Science, 18(1), 1-5. https://doi.org/10.1111/j.1467-8721.2009.01595.x

Van Bavel, J. J., Baicker, K., Boggio, P. S., Capraro, V., Cichocka, A., Cikara, M., ... \& Drury, J. (2020). Using social and behavioural science to support COVID-19 pandemic response. Nature Human Behaviour, 4, 460-471. https://doi.org/10.1038/s41562-020-0884-z

Vittersø, J., \& Nilsen, F. (2002). The conceptual and relational structure of subjective well-being, neuroticism, and extraversion: Once again, neuroticism is the important predictor of happiness. Social Indicators Research, 57(1), 89-118.

Wagnild, G. M., \& Young, H. (1993). Development and psychometric. Journal of Nursing Measurement, 1(2), 165-178.

Wang, H. Z., Sheng, J. R., \& Wang, J. L. (2019). The association between mobile game addiction and depression, social anxiety, and loneliness. Frontiers in public bealth, 7, 247.

Watson, D., Clark, L. A., \& Tellegen, A. (1988). Development and validation of brief measures of positive and negative affect: the PANAS scales. Journal of Personality and Social Psychology, 54(6), 1063. https://doi.org/10.1037//00223514.54.6.1063

Wiese, C. W., Kuykendall, L., \& Tay, L. (2018). Get active? A meta-analysis of leisure-time physical activity and subjective well-being. The Journal of Positive Psychology, 13(1), 57-66

Xiong, J., Lipsitz, O., Nasri, F., Lui, L. M., Gill, H., Phan, L., ... \& McIntyre, R. S. (2020). Impact of COVID-19 pandemic on mental health in the general population: A systematic review. Journal of affective disorders.

Yamaguchi, S. (2020). The Relationship Between Time Spent Playing Mobile Games and Wellbeing. Available at SSRN 3568469

Zelenski, J. M., \& Larsen, R. J. (1999). Susceptibility to affect: A comparison of three personality taxonomies. Journal of Personality, 67(5), 761-791. https://doi.org/10.1111/1467-6494.00072 